\title{
Molecular Characterization of Cronobacter sakazakii Strains Isolated from Powdered Milk
}

\author{
Ondrej Holý ${ }^{1, *}$, Julio Parra-Flores ${ }^{2, *}$ ) , Sarah Lepuschitz ${ }^{3}$, María Paula Alarcón-Lavín ${ }^{2}$, Ariadnna Cruz-Córdova ${ }^{4}$, \\ Juan Xicohtencatl-Cortes ${ }^{4}$, Jetsi Mancilla-Rojano ${ }^{4,5}$, Werner Ruppitsch ${ }^{3}$ and Stephen Forsythe ${ }^{6}$
}

check for

updates

Citation: Holý, O.; Parra-Flores, J.; Lepuschitz, S.; Alarcón-Lavín, M.P.; Cruz-Córdova, A.; Xicohtencatl-Cortes, J.; Mancilla-Rojano, J.; Ruppitsch, W.; Forsythe, S. Molecular Characterization of Cronobacter sakazakii Strains Isolated from Powdered Milk. Foods 2021 10, 20. https://dx.doi.org/10.3390/ foods 10010020

Received: 2 December 2020

Accepted: 19 December 2020

Published: 23 December 2020

Publisher's Note: MDPI stays neutral with regard to jurisdictional claims in published maps and institutional affiliations.

Copyright: (C) 2020 by the authors. Licensee MDPI, Basel, Switzerland. This article is an open access article distributed under the terms and conditions of the Creative Commons Attribution (CC BY) license (https: / / creativecommons.org/ licenses/by/4.0/).
Department of Public Health, Palacký University Olomouc, 77515 Olomouc, Czech Republic

2 Department of Nutrition and Public Health, Universidad del Bío-Bío, Chillán 3800708, Chile; mpalarcon@ubiobio.cl

3 Austrian Agency for Health and Food Safety, Institute for Medical Microbiology and Hygiene, 1220 Vienna, Austria; sarahlepuschitz@gmail.com (S.L.); werner.ruppitsch@ages.at (W.R.)

4 Intestinal Bacteriology Research Laboratory, Hospital Infantil de México Federico Gómez, Mexico City 06720, Mexico; ariadnnacruz@yahoo.com.mx (A.C.-C.); juanxico@yahoo.com (J.X.-C.); mancillajetsi@gmail.com (J.M.-R.)

5 Biological Sciences Graduate Program, Facultad de Medicina, Posgrado en Ciencias Biológicas, Universidad Nacional Autónoma de México, Mexico City 04510, Mexico

6 Adams Hill, Keyworth, Nottinghamshire NG12 5GY, UK; steve.forsythe@foodmicrobe.com

* Correspondence: holy.ondrej@seznam.cz (O.H.); juparra@ubiobio.cl (J.P.-F.)

\begin{abstract}
Cronobacter spp. are opportunistic pathogens of the Enterobacteriaceae family. The organism causes infections in all age groups, but the most serious cases occur in outbreaks related to neonates with meningitis and necrotizing enterocolitis. The objective was to determine the in silico and in vitro putative virulence factors of six Cronobacter sakazakii strains isolated from powdered milk (PM) in the Czech Republic. Strains were identified by MALDI-TOF MS and whole-genome sequencing (WGS). Virulence and resistance genes were detected with the Ridom SeqSphere+ software task template and the Comprehensive Antibiotic Resistance Database (CARD) platform. Adherence and invasion ability were performed using the mouse neuroblastoma (N1E-115 ATCCCRL-2263) cell line. The CRISPR-Cas system was searched with CRISPRCasFinder. Core genome MLST identified four different sequence types (ST1, ST145, ST245, and ST297) in six isolates. Strains 13755-1B and 1847 were able to adhere in 2.2 and $3.2 \times 10^{6} \mathrm{CFU} / \mathrm{mL}$, while $0.00073 \%$ invasion frequency was detected only in strain 1847 . Both strains $13755-1 \mathrm{~B}$ and 1847 were positive for three (50.0\%) and four virulence genes, respectively. The cpa gene was not detected. Twenty-eight genes were detected by WGS and grouped as flagellar or outer membrane proteins, chemotaxis, hemolysins, and invasion, plasminogen activator, colonization, transcriptional regulator, and survival in macrophages. The colistin-resistance-encoding mcr-9.1 and cephalothin-resis-encoding $b l a_{C S A}$ genes and IncFII(pECLA) and IncFIB(pCTU3) plasmids were detected. All strains exhibited CRISPR matrices and four of them two type I-E and I-F matrices. Combined molecular methodologies improve Cronobacter spp. decision-making for health authorities to protect the population.
\end{abstract}

Keywords: Cronobacter sakazakii; whole-genome sequencing; powdered milk; virulence; antibiotic resistance genes; CRISPR-Cas

\section{Introduction}

The Cronobacter genus was first defined by Iversen et al. [1] and further developed by Iversen et al. [2] and Joseph et al. [3] to include the C. sakazakii, C. malonaticus, C. universalis, C. turicensis, C. muytjensii, C. dublinensis, and C. condimenti species [3]. The population groups most affected by Cronobacter spp. are newborns and the elderly. Holý et al. [4] isolated Cronobacter spp. in 82 of 45,000 analyzed samples and found an incidence $(\times 1000$ samples) of 8.7,8.2, and 4.8 in infants under $1 \mathrm{y}$ of age, children between 1 and $4 \mathrm{y}$, and adults over 65 , respectively. The fatality rates associated with general infection range from $42 \%$ 
to $80 \%$ and $15 \%$ to $25 \%$ for neonatal meningitis and septicemia, respectively [5]. The highest incidence and severity has occurred in infants, and a number of outbreaks in neonatal intensive care units have been reported $[5,6]$. Clinical symptoms in infants are primarily meningitis, septicemia, or necrotizing enteritis [7-9]. Other symptoms can include diarrhea and urinary tract infection.

Infections are often associated with the consumption of reconstituted powdered infant formula (RPIF) caused by either intrinsic contamination of powdered infant formula (PIF) or extrinsic contamination of preparation utensils and equipment [10]. Given that it is widespread, Cronobacter spp. can be isolated from PIF, powdered milk, infant cereals and other products, and water [11,12]. Controlling the organism during PIF production is important because Cronobacter spp. strains have been isolated up to 24 months after the PIF was packaged [13]. Studies of Cronobacter spp. incidence in PIF have shown an incidence ranging from $3 \%$ to $30 \%$ [14-17].

The antibiotic resistance profile of Cronobacter is important because the population group consuming PIF and infant products is immunologically vulnerable. Molloy et al. [18] reported that $51 \%$ of 33 C. sakazakii isolated strains were resistant to cephalothin. Carvalho et al. [19] indicated high resistance to cefazolin $(94.4 \%)$ and low resistance to amoxicillin $(9.45 \%)$, cefpodoxime $(5.55 \%)$, streptomycin (1.35\%), and trimethoprim/sulfamethoxazole $(1.35 \%)$. An $80 \%$ resistance to cephalothin was reported in another study [20]. Fei et al. [21] found varying degrees of resistance to cefazolin and $100 \%$ resistance to amoxicillin-clavulanate, ampicillin, and cefazolin in 70 strains of $C$. sakazakii isolated from PIF and corresponding processing environments.

Many virulence traits have been identified in Cronobacter spp. [22,23], including the association with inositol fermentation [24], invasion and adherence in cellular lines such as HEp-2 and $\mathrm{CaCo}$, the presence of endotoxins [25], detection of virulence genes cpa, hly, and sip [22,26], flagella [27], and the $\operatorname{omp} A$ and $\operatorname{omp} X$ genes [28]. In addition, there are other factors such as the use of sialic acid and the presence of a capsule [29]. Strains related to severe cases of meningitis are also associated with clonal complex 4 (CC4) [30]; therefore, it is suggested that not all C. sakazakii strains are equally virulent [6].

Molecular subtyping has long been considered as a useful tool in epidemiological surveillance to establish the similarity of bacteria colonizing a particular ecological habitat. Sub-typing of Cronobacter spp. has used pulsed-field gel electrophoresis (PFGE), multilocus sequence typing (MLST), and, recently, typing by CRISPR-Cas characterization systems [31]. This is possible because the matrices that constitute these systems can differ among closely related strains, since the genetic information acquired as a result of different exposures to phages and plasmids leads to variations in the repeated sequences and spacers that form them. Therefore, the CRISPR-cas profiles can show a better resolution compared with MLST and PFGE; for this reason, they are used to differentiate highly related strains such as Cronobacter spp. Recently, CRISPR-Cas typing was reported as a valuable tool when developing new methods for the early diagnosis of infectious diseases [32]. Whole-genome sequencing (WGS) is a modern tool for the genomic research of Cronobacter spp., and it can be used to expand the original 7-loci MLST scheme to 1836 loci of core genome MLST (cgMLST) [33]. The use of the MLST scheme for clinical, food, and environmental isolates has provided information that is relevant for Cronobacter spp. and its sources of isolation to analyze the severity of the clinical manifestation in several age groups [34].

The complete genome studies of pathogenic strains have greatly improved our knowledge about the virulence and antibiotic resistance genes [35]. This knowledge leads to an understanding of how pathogens survive by using various mechanisms to infect and elicit variable host disease responses. The aim of the present study was to perform a molecular characterization of six C. sakazakii strains isolated from powdered milk in the Czech Republic between 2010 and 2014 in order to identify their virulence potential and the possible presence of antibiotic resistance genes. 


\section{Materials and Methods}

\subsection{Strains Used in This Study}

Strains 1847, 13755-1A, 13755-1B, 12683-2A, 12683-1, and 6227 were used in this study and were isolated from 1450 powdered milk samples produced in the Czech Republic between 2010 and 2014 by three manufacturers, A $(n=1), B(n=4)$, and C ( $n=1)$.

\subsection{Isolation and Primary Species Identification of Cronobacter Sakazakii Isolates}

The $C$. sakazakii strains were isolated according to the methodology described by Iversen et al. [36] and conserved at $-18{ }^{\circ} \mathrm{C}$. Isolates were cultured on Columbia blood agar plates (bioMérieux, Marcy-l'Étoile, France) overnight at $37^{\circ} \mathrm{C}$ to identify them. Primary species identification from single colonies was performed by matrix-assisted laser desorption/ionization time-of-flight mass spectrometry (MALDI-TOF-MS) (Bruker, Billerica, MA, USA) and with the MBT Compass IVD software 4.1.60 (Bruker) described by Lepuschitz et al. [37].

\subsection{Whole-Genome Sequencing (WGS) Data Analysis}

The DNA isolation, quantification, and preparation of sequence-ready libraries for whole-genome sequencing (WGS) were as indicated by Lepuschitz et al. [38]. The Sequencing Coverage Calculator (https://www.illumina.com) was used to calculate a desired mean coverage $>$ fold- 80 .

Raw reads were de novo assembled with the SPAdes version 3.9.0 [39] and processed with the SeqSphere+ software version 5.1.0 (Ridom GmbH, GmbH, Münster, Germany). A gene-by-gene genome-wide comparison was performed for bacterial typing by the MLST+ task template function of SeqSphere+, as previously described [40], and the core genome multilocus sequence type (cgMLST) gene set was defined according to Lepuschitz et al. [38]. Based on the defined cgMLST scheme, isolates were visualized as a minimum spanning tree (MST) to identify genotypic relationships. Sequences of the seven housekeeping genes of the usual MLST scheme were extracted and queried against the Cronobacter MLST database and the sequence types (STs) in silico were determined [6].

\subsection{O-Serotype Determination Analysis}

The gene clusters of the gnd and galF loci are specific to the O-serotype region. They were identified by analyzing WGS sequences via the BIGSdb tools in the PubMLST database (http:/ / pubmlst.org/cronobacter/) [31].

\subsection{Adherence Assay}

The mouse neuroblastoma (N1E-115 ATCC CRL-2263, Manassas, USA) cell line was used for the adherence assay. The N1E-115 cell line was cultured in Dulbecco's Modified Eagle Medium (DMEM) with $4.5 \mathrm{~g} / \mathrm{L}$ glucose (GIBCO, MA, USA). In addition, it was supplemented with 7\% fetal bovine serum (FBS) (GIBCO, MA, USA) and differentiated in DMEM medium to which 2\% FBS and 1.25\% dimethyl sulfoxide was added for $5 \mathrm{~d}$. The cells $\left(1 \times 10^{5}\right.$ cells $\left./ \mathrm{mL}\right)$ were sown in 24 -well plates (Corning Life Sciences, NY, USA) and infected at a multiplicity of infection100:1. All the studied isolates were previously cultured in Luria broth (LB). Infection was carried out at $37^{\circ} \mathrm{C}$ for $4 \mathrm{~h}$ and $5 \% \mathrm{CO}_{2}$. After incubation, the cells were washed with PBS $1 \times$ and the bacteria removed by adding $1 \mathrm{~mL}$ $0.1 \%$ Triton X-100 (Amresco, OH, USA). Afterward, serial dilutions were plated on LB to determine the colony-forming units (CFU) of bacteria adhering to the N1E-115 cell [22]. This assay was repeated twice and in duplicate; the data were expressed as the means plus the standard deviation of the assay results.

\subsection{Invasion Assay}

The conditioning of the monolayers of cell line N1E-115 and infection time were performed as previously described in Section 2.5. After a 4-h incubation, the infected monolayers were washed with PBS $1 \times$ and incubated with $1 \mathrm{~mL}$ DMEM with $300 \mu \mathrm{g} / \mathrm{mL}$ 
lysozyme (Sigma-Aldrich, MI, USA) and $100 \mu \mathrm{g} / \mathrm{mL}$ gentamicin (Sigma-Aldrich, MI, USA) at $37^{\circ} \mathrm{C}$ for $2 \mathrm{~h}$ and $5 \% \mathrm{CO}_{2}$. After incubation, cells were washed three times with PBS $1 \times$, detached with $1 \mathrm{~mL} 0.1 \%$ Triton X-100, and plated on LB. Invasion frequencies were calculated as the number of bacteria surviving incubation with gentamicin and lysozyme divided by the total number of bacteria present when this antibiotic is not used (bacterial adherence) [22]. This assay was conducted twice and in duplicate; data were expressed as invasion frequency $(\%)$.

\subsection{In Vitro Virulence Gene Detection}

Plasminogen activator (cpa), hemolysin (hly), siderophore-interacting protein (sip), flagellin $(f l i C)$, autotransporter (aut), and outer membrane protein (ompA) genes were detected by polymerase chain reaction (PCR) [23]. Amplified products were stained and visualized on $1.5 \%$ agarose gel with a $1.0 \mathrm{mg} / \mathrm{mL}$ ethidium bromide solution using a gel imaging system $[22,23]$.

\subsection{Antibiotic Resistance Profile}

The disk diffusion method was used in accordance with the recommendations of EUCAST 2019. Commercial antibiotic disks were used and consisted of ampicillin (10 $\mu \mathrm{g})$, amikacin $(30 \mu \mathrm{g})$, levofloxacin $(5 \mu \mathrm{g})$, cephalothin $(30 \mu \mathrm{g})$, cefotaxime $(30 \mu \mathrm{g})$, ceftriaxone $(30 \mu \mathrm{g})$, chloramphenicol $(30 \mu \mathrm{g})$, gentamicin $(10 \mu \mathrm{g})$, netilmicin $(30 \mu \mathrm{g})$, nitrofurantoin $(300 \mu \mathrm{g})$, cefepime $(30 \mu \mathrm{g})$, and sulfamethoxazole trimethoprim $(25 \mu \mathrm{g})$. The resistance/susceptibility profiles were determined according to the manufacturer's instructions. The Escherichia coli ATCC 25922 strain was used as a control.

\subsection{In Silico Detection of Virulence and Antibiotic Resistance Genes from Whole Genome Sequencing (WGS) Data}

The existence of virulence genes was confirmed by the Task Template function in SeqSphere+ for WGS data included in the virulence factor database (http:/ / www.mgc. ac.cn/VFs /). Thresholds for the target scan procedure were set at $\geq 90 \%$ to identify the reference sequence and $\geq 99 \%$ aligned to the reference sequence [38].

The presence of antimicrobial resistance genes was determined by the Comprehensive Antibiotic Resistance Database (CARD) with the "perfect" and "strict" default settings for sequence analysis [41] and Task Template AMRFinderPlus 3.2.3 available in the Ridom SeqSphere +7.0 software using the EXACT method: $100 \%$ sequence match over $100 \%$ of the length of a protein in the database that is not a named allele. The BLAST alignment is $>90 \%$ of length and $>90 \%$ identified to a protein in the AMRFinderPlus database.

\subsection{Plasmid Detection}

We used the PlasmidFinder 1.3 function to detect the plasmids [42], available from the Center for Genomic Epidemiology (http:/ / www.genomicepidemiology.org/).

\subsection{Profiling of CRISPR-Cas Loci}

The search and characterization of the CRISPR matrices and the associated cas genes were determined with CRISPRCasFinder [43], which is available from the Institut de Biologie Intégrative de la Cellule and Université Paris-Saclay server (https: / / crisprcas.i2bc. paris-saclay.fr). The CRISPRDigger program was used to determine the type of CRISPR-Cas system [44].

\section{Results and Discussion}

Primary species identification by MALDI-TOF MS identified the six strains isolated from powdered milk in the Czech Republic between 2010 and 2014 as C. sakazakii. Further analysis by WGS identified four different STs among the six isolates (ST1: 13755-1B, 126831; ST145: 6227; ST245: 1847, 13755-1A; ST297: 12683-2A) (Table 1), and isolates with 
concordant STs shared the same O-serotype-specific gene loci for gnd and galF (ST1: 2 (galF) and 1 (gnd); ST145: 25 and 23; ST245: 45 and 58; ST297: 17 and 18).

Table 1. Cronobacter sakazakii strains isolated from powdered milk.

\begin{tabular}{cccccccc}
\hline Strain & NGS ID & Identification & ST & Source & Country & $\begin{array}{c}\text { Year of } \\
\text { Isolation }\end{array}$ & Manufacturer \\
\hline *1847 & $510284-18$ & C. sakazakii & 245 & Powdered milk & Czech Republic & 2010 & A \\
$13755-1 \mathrm{~A}$ & $510192-19$ & C. sakazakii & 245 & Powdered milk & Czech Republic & 2014 & $\mathrm{~B}$ \\
$13755-1 \mathrm{~B}$ & $510193-19$ & C. sakazakii & 1 & Powdered milk & Czech Republic & 2014 & $\mathrm{~B}$ \\
$12683-1$ & $510285-19$ & C. sakazakii & 1 & Powdered milk & Czech Republic & 2014 & $\mathrm{~B}$ \\
$12683-2 \mathrm{~A}$ & $510194-19$ & C. sakazakii & 297 & Powdered milk & Czech Republic & 2014 & $\mathrm{~B}$ \\
6227 & $510555-19$ & C. sakazakii & 145 & Powdered milk & Czech Republic & 2014 & C \\
\hline
\end{tabular}

* ID 1482: PubMLST/Cronobacter. NGS ID: Next Generation Sequencing Identification; ST: sequence type.

Calculation of a Minimum Spanning Tree (MST) (Figure 1) revealed four singleton isolates with a maximum allelic difference of 2642 and identified the presence of one cluster comprising two isolates, both belonging to ST245 and sharing the same set of cgMLST loci (isolates 13755-1A and 1847). To date, C. sakazakii ST245 has been primarily isolated from clinical cases; however, it has not been previously described in PIF. Meanwhile, C. sakazakii ST145 has been isolated in spices in China and soil in Germany (www.PubMLST.org/ cronobacter/). Previously isolated from PIF, ST1 was detected twice in the present study and has been associated with fatal meningitis, septicemia, and urinary tract infections [45]. The detection of these C. sakazakii clones (ST1, ST245) in PIF and human samples confirms contaminated PIF as a possible source of infection and a potential health risk to infants. Lepuschitz et al. [38] concluded that the accurate identification of C. sakazakii is still a diagnostic challenge for many laboratories, and the current use of incorrect or outdated detection schemes would explain the low prevalence of $C$. sakazakii clinical isolates found in their EU study. Whole-genome sequencing can be applied to foodborne outbreaks to establish epidemiological links. It can also identify virulence loci, antibiotic resistance, and genotype, thus facilitating more accurate risk management [46].

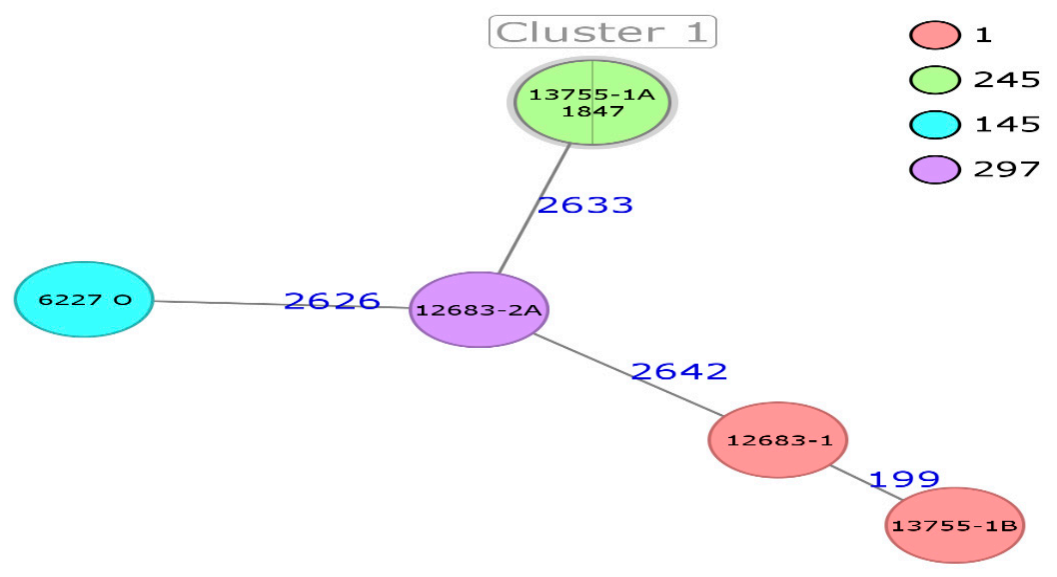

Figure 1. Minimum spanning tree (MST) of six Cronobacter sakazakii strains isolated from powdered milk (PM). The MST calculation was based on the defined cgMLST scheme comprising 2831 target genes. Isolates are represented as colored circles according to classical multilocus sequence typing (MLST). Blue numbers accord to the allelic difference between isolates. The isolates with closely related genotypes are marked as a cluster. 
Cronobacter spp. exhibit diverse virulence factors in the pathogenic process to intestinal cells such as adherence, invasion, toxin and hemolysin genes, and the ability to resist destruction by human serum [47-50]. Only strains 1847 (ST245) and 13755-1B (ST1) were selected to conduct the assays in a cell line because the STs were previously isolated from clinical cases. The strains were able to adhere to the cell line N1E-115 ATCC CRL-2263 with values of 2.2 and $3.2 \times 10^{6} \mathrm{CFU} / \mathrm{mL}$ for strains 13755 and 1847, respectively (Figure 2). Adherence to intestinal cells is the first step in the pathogenic process [51]. This virulence characteristic has been studied in different cell lines such as N1E-115, HEp-2, CaCo-2, HBMEC, and IEC-6; the results have shown different variations depending on the type of cell line and strain being used $[48,49,52]$. The C. sakazakii strains isolated in clinical cases exhibited adherence rates that are higher $(0.915 \%)$ than those from other sources $(0.0002 \%)$ [23]. For the invasion assay, only strain 1847 was able to invade at a lower rate $(0.00073 \%)$ compared with results reported by Mange et al. [48], Townsend et al. [49], Parra-Flores et al. [20], and Holý et al. [23].

(A)

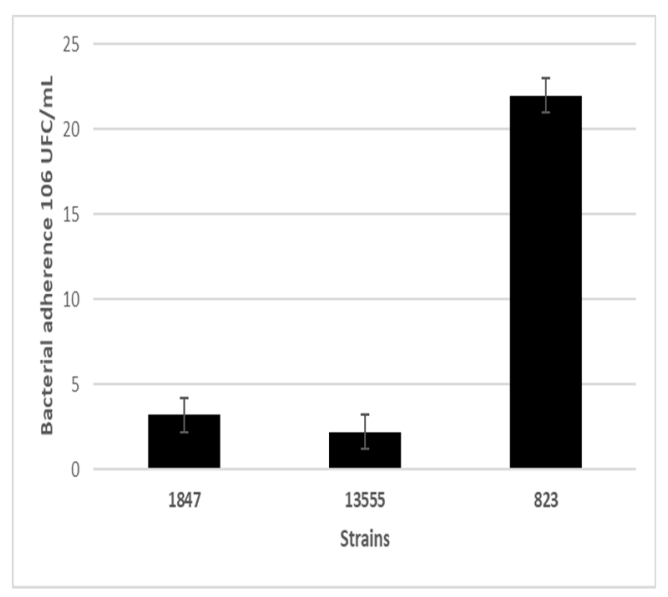

(B)

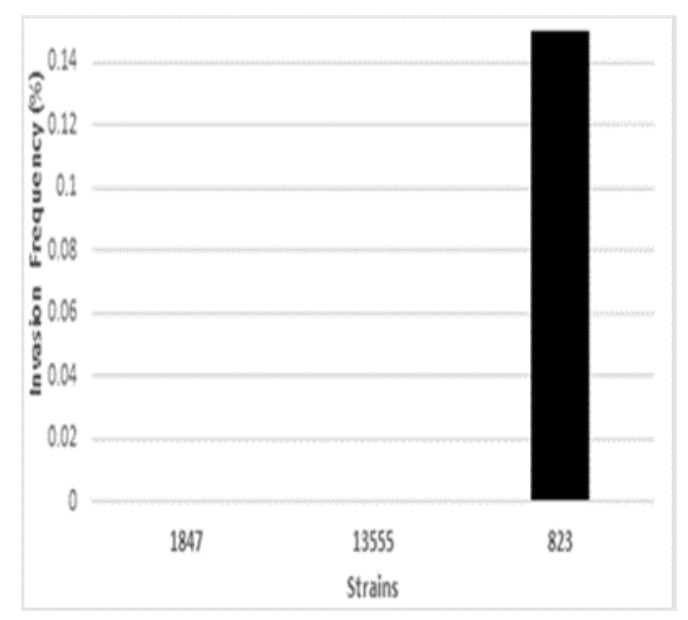

Figure 2. Bacterial adherence (A) and invasion frequency (B) of Cronobacter sakazakii on the neuroblastoma (NT) cell line.

Virulence factors must be studied to understand the pathogenic process and its relationship with the host [53]. In the present study, when evaluating the presence of six virulence factors by PCR, strain 13755-1B amplified three genes ompA, aut, and fliC and strain 1847 amplified the four genes ompA, aut, fliC, and hlyA (Table 2).

Table 2. Presence of virulence factors by polymerase chain reaction (PCR).

\begin{tabular}{cccccccc}
\hline C. sakazakii Strain (ST) & \multicolumn{7}{c}{ Gene } \\
\cline { 2 - 7 } & hlyA & ompA & aut & fliC & inv & cpa \\
\hline 13755-1B (1) & - & + & + & + & - & - \\
1847 (245) & + & + & + & + & - & - \\
823 (ATCC BAA-894) (1) control strain & + & + & + & + & + & + \\
\hline
\end{tabular}

The presence of a gene is represented by "+" and the absence of a gene is represented by "-".

The results of the analysis of the whole genome of the six C. sakazakii strains was the presence of 28 virulence genes; these were grouped as flagellar or outer membrane proteins, chemotaxis, hemolysins, and invasion (labp), plasminogen activator (cpa), colonization $(m v i N)$, transcriptional regulator (sdiA), and survival in macrophages (Table 3). Virulence values determined by WGS were comparable to the PCR results. For example, the hly gene was amplified by PCR only for strain 1847, although it was present in both strains when analyzed in silico by WGS. Meanwhile, the inv gene was not detected by PCR 
in neither of the two evaluated strains; however, it was present in strain 1847 when analyzed by WGS. These results in strains 1847 and 13755-1B concur with the previously mentioned invasion and adherence assays. The cpa gene was not amplified by PCR and was not present in WGS. This can be explained by the fact that a greater number of strain activations for experimental work have produced some mutations that cause changes or non-expression of a certain phenotypic or genotypic quality in the strains being evaluated [54]. The OmpA protein is more than $80 \%$ the same as has the E. coli $\mathrm{K} 1$ protein, which significantly participates in the invasion of neonatal blood-brain barrier cells [55]. The proteins OmpA and OmpX of Cronobacter spp are important for adhesion to the CaCo-2 and INT-407 cell lines; they are also capable of causing damage to intestinal cells and eliminating villi $[28,48]$. The Cpa protein is considered as a key virulence factor involved in serum resistance and invading C. sakazakii. Evolutionary evidence suggests that the cpa locus can be a specific locus for C. sakazakii and C. universalis [26]. However, some ST8 clinical strains of $C$. sakazakii that have the pESA3 virulence plasmid do not have cpa yet remain are considered extremely virulent. This suggests there are other virulence factors besides cpa that can be responsible for the infection [56]. The Hly (type III hemolysin) is a protein of the external membrane found in several pathogens with hemolytic ability $[57,58]$. It was present when analyzing the C. sakazakii BAA-894 strain isolated from the 2001 NICU outbreak in the United States [59]. The autotransporter gene (aut) has been identified in E. coli and other Enterobacteriaceae; it is associated with adherence, aggregation, invasion, biofilm formation, and toxicity [60]. The fliC gene is a flagellar protein and a subunit of the flagellar organelle; it is primarily responsible for bacterial motility, adherence ability, and virulence traits of microorganisms [61]. Hoeflinger and Miller [62] evaluated flagellamediated autoaggregation and determined that the flagella play an important role in the pathogenesis of C. sakazakii. Aldubyan et al. [63] established the significant role of flagella in the adherence and invasion of pathogens that contain $f l i C$. Decreased motility has been related to the loss of the $\mathrm{fliC}$ gene. Dingle et al. [64] determined the important role of the FliC and FliD flagellar subunit, which increased the adherence to Caco-2 cells compared with the wild type; mutants are also more virulent. These virulence factors established as flagella-associated genes, outer membrane protein genes, and some regulators can be related to motility, biofilm formation, and virulence characterization in Cronobacter [65].

When evaluating the antibiotic resistance profile of the two selected strains (1847 and 13755-1B), both were resistant to cephalothin, whereas strain 13755-1B was resistant to ceftazidime and strain 1847 to ampicillin. Several authors have identified the resistance of C. sakazakii to cephalothin, ceftazidime, and ampicillin $[18,66,67]$. Some strains were resistant to ampicillin, cephalothin, and cefotaxime in a collection of Cronobacter spp. strains isolated by Parra et al. [68]. In contrast, Holý et al. [23] found no resistant strains. A recent study by Parra et al. [17] found that $100 \%$ of the C. sakazakii strains isolated from powdered milk were resistant to cefotaxime and ampicillin. In addition, resistance to cefepime and amikacin was $60 \%$ and $40 \%$ for ceftriaxone. In addition, one strain was resistant to six of the 12 evaluated antibiotics (54.5\%), while another C. sakazakii isolated strain was resistant to five $(50 \%)$. Resistance values in the present study are higher than those reported in the current literature, and should be studied in the event of the appearance of multiresistant $C$. sakazakii strains in powdered milk (PM) and the associated health risk to infants and children. 
Table 3. Virulence gene distribution among six strains of Cronobacter sakazakii by whole-genome sequencing (WGS).

\begin{tabular}{|c|c|c|c|c|c|c|c|}
\hline Virulence Gene & Function & $\begin{array}{c}1847 \\
\text { (ST245) }\end{array}$ & $\begin{array}{c}\text { 13755-1A } \\
\text { (ST245) }\end{array}$ & $\begin{array}{c}\text { 13755-1B } \\
\text { (ST1) }\end{array}$ & $\begin{array}{c}\text { 12683-1 } \\
\text { (ST1) }\end{array}$ & $\begin{array}{c}\text { 12683-2A } \\
\text { (ST 297) }\end{array}$ & $\begin{array}{c}6227 \\
\text { (ST145) }\end{array}$ \\
\hline$f \lg B$ & motility & + & + & + & + & + & + \\
\hline flgK & flagellar hook- tassociated protein 1 & + & + & + & + & + & + \\
\hline$f \lg L$ & flagellar hook- associated protein 3 & + & + & + & + & + & + \\
\hline flgM & negative regulator of flagellin synthesis & + & + & + & + & + & + \\
\hline$f \lg N$ & flagella synthesis FlgN protein & + & + & + & + & + & + \\
\hline flhD & flagellar hook- associated protein 2 & + & + & + & + & + & + \\
\hline fliA & flagellar operon FliA & + & + & + & + & + & + \\
\hline fliC & flagellin & + & + & + & + & + & + \\
\hline fliD & flagellar hook- associated protein 2 & + & + & + & + & + & + \\
\hline fliR & flagellar biosynthetic FliR protein & + & + & + & + & + & + \\
\hline fliT & flagella FliT protein & + & + & + & + & + & + \\
\hline fliZ & FliZ protein & + & + & + & + & + & + \\
\hline lolA & outer membrane lipoprotein carrier protein & + & + & + & + & + & + \\
\hline $\operatorname{mot} B$ & chemotaxis MotA protein & + & + & - & + & + & + \\
\hline ompW & transmembrane transport & + & + & + & + & + & + \\
\hline sdiA & LuxR family transcriptional regulator & + & + & + & + & + & + \\
\hline tolC & outer membrane channel protein & + & + & + & + & + & + \\
\hline $\operatorname{Msg} A$ & survival in macrophage & + & + & + & + & + & + \\
\hline MviN & protective immunity and colonization in Salmonella & + & + & + & + & + & + \\
\hline$c p a$ & plasminogen activator & - & - & + & + & + & + \\
\hline hha & hemolysin expression modulating protein & + & + & + & + & + & + \\
\hline hly III & hemolysin III & + & + & + & + & + & + \\
\hline ompA & adhesion cell; cell death induction; biofilm formation & + & + & + & + & + & + \\
\hline ompX & adhesion cell & + & + & + & + & + & + \\
\hline blc & outer membrane lipoprotein & + & + & + & + & + & + \\
\hline cheR & chemotaxis protein methyltransferase & + & + & - & + & + & + \\
\hline cheY & response regulator of chemotaxis family & + & + & + & + & + & + \\
\hline$l a b p$ & epithelial cell invasion and lipid A production by LpxA & + & - & + & - & - & - \\
\hline
\end{tabular}


A total of 12 genes were detected in silico by CARD, thus conferring antibiotic resistance against beta-lactams, fluoroquinolones, aminoglycosides, and phosphonates (Table 4). Of the 12 antibiotic resistance genes, including antibiotic efflux $(n=8)$, antibiotic target alteration (3), and antibiotic target protection (1), 11 were present in all the isolates. The antibiotic target protection gene $(\mathrm{vgaC})$ was present in only three of the six isolates and the marA gene, whose function is as a transcription factor that upregulates multidrug efflux and downregulates membrane permeability, was found in all the isolates. As in our study, Aly et al. [69] found $m s b A$, emrR, H-NS, emrB, marA, CRP, and PBP3 to be associated with resistance to several antibiotics such as beta-lactams, tetracycline, macrolide, fluoroquinolone, penams, cephalosporin, and cephamycin. Active flow pumps provide a mechanism to increase resistance by improving the survival of enterobacteria in the gastrointestinal tract of the host and allowing the invasion of microvascular endothelial cells in the brain [70,71]. Studies have demonstrated that the abuse of antibiotics in food environments and the presence of several antibiotic resistant operons ( $m a r$ ) can cause Cronobacter spp. to develop resistance to many different antibiotics $[66,67,72]$.

When complementing our research with the AMRFinderPlus tool, strains 1847, 137551A, 12683-1, and 12683-2A exhibited the mcr-9.1 gene associated with resistance to colistin and the gene $b l a_{C S A}$ that provides resistance to cephalothin in $100 \%(6 / 6)$ of the strains evaluated in the study. The $m c r-9.1$ gene is considered as a new gene that can attribute phenotypic resistance to colistin in various Enterobacteriaceae spp. reported in Salmonella typhimurium, Escherichia coli, and Enterobacter hormaechei in 2019. They can circulate without being detected, unless induced by colistin [73-75]. The presence of mobile genes that are resistant to colistin ( $\mathrm{mcr}$ ) is a worldwide concern because colistin is perceived as a last resort antimicrobial to treat infections caused by multi-resistant Enterobacteriaceae [76]. The bla $a_{C S A}$ family of genes, resistant to class $C \beta$-lactamase, was described by Müller et al. [77]. The members of this family of $\beta$-lactamases are not inducible and are regarded as cephalosporinases. Jang et al. [56] found that the $C$. sakazakii strains isolated from houseflies had class $C$ bla $C S A$ resistance genes. They also encountered variants of class C bla resistance genes identified as CSA-2 or CSA-1.

Strains 1847 and 13755-1A, present in IncFII (pECLA) plasmid (Table 5), are associated with antibiotic resistance genes in Cronobacter, such as carbapenemase genes $\Delta$ intI1$b l a_{I M P-26}, b l a_{C S A}, b l a_{C M A}$, and IS26 flanking bla $a_{S F O-1}[77,78]$.

Strain 12683-2A exhibited an IncFIB (pCTU1) plasmid, which is also associated with antibiotic resistance (Table 4). Meanwhile, pCTU1 encodes similar gene groups or gene clusters comprising the plasmid backbone, a replication gene similar to RepFIB (repA), two iron acquisition systems, a siderophore similar to aerobactin (called cronobactin), a group of iron $\mathrm{ABC}$ transport genes, and several species-specific virulence gene determinants such as the cpa gene [79]. Therefore, the absence of pCTU1 type plasmids in strains 1847 and 13755-1A can explain the non-detection of the cpa gene by PCR and WGS [56]. 
Table 4. Antibiotic-resistant genes identified by Comprehensive Antibiotic Resistance Database (CARD).

\begin{tabular}{|c|c|c|c|c|c|c|c|c|}
\hline $\begin{array}{l}\text { Best Hit Antibiotic } \\
\text { Resistance } \\
\text { Ontology (ARO) }\end{array}$ & Drug Class & Resistance Mechanism & $\begin{array}{c}1847 \\
(\mathrm{ST} 245)\end{array}$ & $\begin{array}{l}\text { 13755-1A } \\
\text { (ST245) }\end{array}$ & $\begin{array}{l}\text { 13755-1B } \\
\text { (ST1) }\end{array}$ & $\begin{array}{l}\text { 12683-1 } \\
\text { (ST1) }\end{array}$ & $\begin{array}{l}\text { 12683-2A } \\
\text { (ST297) }\end{array}$ & $\begin{array}{c}6227 \\
(\mathrm{ST} 145)\end{array}$ \\
\hline$C R P$ & $\begin{array}{c}\text { fluoroquinolone antibiotic; macrolide } \\
\text { antibiotic; penam }\end{array}$ & antibiotic efflux & + & + & + & + & + & + \\
\hline $\operatorname{mar} R$ & $\begin{array}{l}\text { monobactam; triclosan; rifamycin antibiotic; } \\
\text { penem; cephamycin; fluoroquinolone antibiotic; } \\
\text { penam; phenicol antibiotic; glycylcycline; } \\
\text { tetracycline antibiotic; } \\
\text { cephalosporin; carbapenem } \\
\text { fluoroquinolone antibiotic; macrolide antibiotic; }\end{array}$ & $\begin{array}{l}\text { antibiotic efflux; reduced } \\
\text { antibiotic permeability }\end{array}$ & + & + & + & + & + & + \\
\hline$H-N S$ & $\begin{array}{l}\text { penam; tetracycline antibiotic; } \\
\text { cephalosporin; cephamycin }\end{array}$ & antibiotic efflux & + & + & + & + & + & + \\
\hline EF-Tu & elfamycin antibiotic & antibiotic target alteration & + & + & + & + & + & + \\
\hline $\operatorname{mar} A$ & $\begin{array}{l}\text { antibiotic; penam; phenicol antibiotic; } \\
\text { glycylcycline; tetracycline } \\
\text { antibiotic; cephalosporin }\end{array}$ & $\begin{array}{l}\text { antibiotic target alteration; } \\
\text { antibiotic efflux }\end{array}$ & + & + & + & + & + & + \\
\hline emrR & fluoroquinolone antibiotic & antibiotic efflux & + & + & + & + & + & + \\
\hline adeF & tetracycline antibiotic; fluoroquinolone antibiotic & antibiotic efflux & + & + & + & + & + & + \\
\hline$m s b A$ & nitroimidazole antibiotic & antibiotic efflux & + & + & + & + & + & + \\
\hline $\operatorname{vg} a C$ & $\begin{array}{l}\text { streptogramin antibiotic; } \\
\text { pleuromutilin antibiotic }\end{array}$ & antibiotic target protection & + & + & - & - & + & - \\
\hline GlpT & fosfomycin & antibiotic target alteration & + & + & + & + & + & + \\
\hline РBP3 & $\begin{array}{l}\text { penam; cephalosporin; cephamycin; } \\
\text { monobactam; carbapenem }\end{array}$ & antibiotic target alteration & + & + & + & + & + & + \\
\hline
\end{tabular}

The presence of a gene is represented by " +" and the absence of a gene is represented by "-". 
Table 5. Presence of plasmids in Cronobacter sakazakii strains by whole genome sequencing (WGS).

\begin{tabular}{cccc}
\hline Strains (ST) & Plasmids & Accession Number & Function \\
\hline 1847 (1); 13755-1A (245) & IncFII(pECLA) & CP001919 & $\begin{array}{c}\text { Antibiotic } \\
\text { resistance }\end{array}$ \\
12683-2A (297) & IncFIB(pCTU3) & FN543096 & \\
\hline
\end{tabular}

The CRISPR-Cas systems are associated with the acquisition of mobile genetic material through horizontal transfer; they are regarded as an immunity system. These contain information that the bacteria have acquired through the virus and plasmids. They consist of two principal components: a guide RNA (gRNA) and a non-specific endonuclease associated with genes that code for cas, both of which are indispensable for the activity and incorporation of genetic material [80]. When analyzing the genomes of the six C. sakazakii strains in the present study, we found that $100 \%(6 / 6)$ exhibited a series of repeated sequences and spacers, which constitute matrices associated with type I-F and I-E CRISPR systems; the four strains 13755-1A, 13755-1B, 12683-2A, and 12683-1 were included in both systems (Table 6). Regarding the characteristics of the CRISPR matrices, we encountered five different repeated consensus sequences associated with the type I-E system, and the sequence GTGTTCCCCGCGCGAGCGGGGATAAACCG was the most frequent because it was associated with four of the six strains under study; however, strains 13755-1A and 6227 exhibited only one repeated consensus sequence. For the type I-F system, three different repeated sequences were found; the sequence GTTCACTGCCGTACAGGCAGCTTAGAAA was the most frequent and sequence TTTCTAAGCTGCCTGTACGGCAGTGAAC was distinctive of strain 12683-A. Although the sequences that characterize each system can be identical, one aspect that differs from strain to strain is the number of repeated sequences and spacers that characterize them. The above-mentioned strain had the largest matrices, with a maximum of up to 49 repeated sequences and 53 spacers for the I-F system and 58 repeated sequences and 62 spacers for the I-E system. This provides us with knowledge about the information this microorganism is acquiring from the bacteriophages and plasmids.

The strains that exhibit the same sequence type can have different CRISPR matrices; for example, strains 1847 and 13755-1A associated with ST245 exhibited different types of CRISPR-Cas systems, whereas the opposite was observed in strains 12683-1 and 13755-1B, which had the same sequence type and the same CRISPR matrices. This is relevant because this system has been used as a typing method in different microorganisms. When analyzing 29 genomes of C. sakazakii ST1, Ogrodzki and Forsythe [81] found that all the strains exhibited the same type I-E system and three spacer matrices with conserved patterns. In addition, the use of CRISPR spacer matrix profiles compared with MLST show greater intra-species discrimination power; it is a useful tool to study future Cronobacter outbreaks by more accurately relating clinical cases, food sources, and production sites associated with and outbreak [82]. While it was initially believed that $C$. sakazakii had only one type of CRISPR system, Zeng et al. [83] indicated that $94.5 \%$ of the analyzed C. sakazakii strains showed more than one CRISPR and these were in conserved zones of its genome. Although each type of CRISPR-Cas system is characterized by certain associated cas genes, the cas 1 and cas 2 genes are indispensable for integrating and processing the information acquired by the bacterium. It has also been suggested that if any of these genes are not present, the system loses the ability to acquire information, and therefore can no longer integrate information into the CRISPR locus [84]. 
Table 6. Profiling of CRISPR-Cas loci among Cronobacter sakazakii strains.

\begin{tabular}{|c|c|c|c|c|c|c|}
\hline Strains & $\begin{array}{l}\text { Sequence } \\
\text { Type (ST) }\end{array}$ & $\begin{array}{c}\text { Operon } \\
\text { Structure Type }\end{array}$ & $\begin{array}{l}\text { Number of } \\
\text { CRISPR } \\
\text { Arrays per } \\
\text { Strain }\end{array}$ & $\begin{array}{l}\text { Maximum } \\
\text { Number of } \\
\text { Spacers per } \\
\quad \text { Strain }\end{array}$ & $\begin{array}{l}\text { Sequences } \\
\text { with Cas } \\
\text { Cluster }\end{array}$ & Repeat Consensus/cas Genes \\
\hline 1847 & 245 & Type I-E Cas & $29 / 7$ & $32 / 9$ & 1 & $\begin{array}{c}\text { GTTCACTGCCGTACAGGCAGCTTAGAAA/ } \\
\text { CTGTTCCCCGCGCGAGCGGGGATAAACCG/ } \\
\text { Cas3_0_I, Cse1_0_IE, Cse2_0_IE, Cas7_0_IE, Cas5_0_IE, Cas6_0_IE, } \\
\text { Cas1_0_IE, Cas2_0_IE. }\end{array}$ \\
\hline 13755-1B & 1 & $\begin{array}{l}\text { Type I-E Cas } \\
\text { Type I-F Cas }\end{array}$ & $\begin{array}{c}22 / 30 \\
14\end{array}$ & $\begin{array}{c}24 / 32 \\
16\end{array}$ & $\begin{array}{l}1 \\
1\end{array}$ & $\begin{array}{c}\text { CTGTTCCCCGCGCGAGCGGGGATAAACCG/ } \\
\text { GTGTTCCCCGCGCGAGCGGGGATAAACCG/ } \\
\text { Cas3_0_I, Cse1_0_IE, Cse2_0_IE, Cas7_0_IE, Cas5_0_IE, Cas6_0_IE, } \\
\text { Cas1_0_IE, Cas2_0_IE. } \\
\text { GTTCACTGCCGTACAGGCAGCTTAGAAA/ } \\
\text { Cas1_0_IF, Cas3-Cas2_0_IF, Cas6_0_IF, Csy1_0_IF, Csy2_0_IF, Csy3_0_IF. }\end{array}$ \\
\hline $12683-2 \mathrm{~A}$ & 297 & $\begin{array}{l}\text { Type I-F Cas } \\
\text { Type I-E Cas }\end{array}$ & $\begin{array}{c}49 \\
20 / 58\end{array}$ & $\begin{array}{c}53 \\
22 / 62\end{array}$ & $\begin{array}{l}1 \\
1\end{array}$ & $\begin{array}{c}\text { TTTCTAAGCTGCCTGTACGGCAGTGAAC/ } \\
\text { Cas1_0_IF, Cas3-Cas2_0_IF, Cas6_0_IF, Csy1_0_IF, Csy2_0_IF, Csy3_0_IF. } \\
\text { CTGTTCCCCGCGCGAGCGGGGATAAACCG/ } \\
\text { GTGTTCCCCGCGCGAGCGGGGATAAACCG/ } \\
\text { Cas3_0_I, Cse1_0_IE, Cse2_0_IE, Cas7_0_IE, Cas5_0_IE, Cas6_0_IE, } \\
\text { Cas1_0_IE,CCas2_0_IE. }\end{array}$ \\
\hline
\end{tabular}


Table 6. Cont.

\begin{tabular}{|c|c|c|c|c|c|c|}
\hline Strains & $\begin{array}{l}\text { Sequence } \\
\text { Type (ST) }\end{array}$ & $\begin{array}{c}\text { Operon } \\
\text { Structure Type }\end{array}$ & $\begin{array}{l}\text { Number of } \\
\text { CRISPR } \\
\text { Arrays per } \\
\text { Strain }\end{array}$ & $\begin{array}{l}\text { Maximum } \\
\text { Number of } \\
\text { Spacers per } \\
\text { Strain }\end{array}$ & $\begin{array}{l}\text { Sequences } \\
\text { with Cas } \\
\text { Cluster }\end{array}$ & Repeat Consensus/cas Genes \\
\hline $12683-1$ & 1 & $\begin{array}{l}\text { Type I-E Cas } \\
\text { Type I-F Cas }\end{array}$ & $\begin{array}{c}28 / 31 \\
14\end{array}$ & $\begin{array}{l}29 / 32 \\
15\end{array}$ & $\begin{array}{l}1 \\
1\end{array}$ & $\begin{array}{c}\text { CTGTTCCCCGCGCGAGCGGGGATAAACCG/ } \\
\text { GTGTTCCCCGCGCGAGCGGGGATAAACCG/ Cas3_0_I, Cse1_0_IE, } \\
\text { Cse2_0_IE, Cas7_0_IE, Cas5_0_IE, Cas6_0_IE, Cas1_0_IE, Cas2_0_IE. } \\
\text { GTTCACTGCCGTACAGGCAGCTTAGAAA/ } \\
\text { Cas1_0_IF, Cas3-Cas2_0_IF, Cas6_0_IF, Csy1_0_IF, Csy2_0_IF, Csy3_0_IF }\end{array}$ \\
\hline 6227 & 145 & Type I-E Cas & $15 / 13$ & $16 / 12$ & 1 & $\begin{array}{c}\text { CGGTTTATCCCCGCTCGCGCGGGGAACGG/ } \\
\text { GTGTTCCCCGCGCGAGCGGGGATAAACCG// Cas1_0_IE, } \\
\text { Cas2_0_IE, Cas5_0_IE, Cas6_0_IE, Cas7_0_IE, Cse1_0_IE, Cse2_0_IE. }\end{array}$ \\
\hline
\end{tabular}




\section{Conclusions}

Cronobacter sakazakii was confirmed in six of the 1450 evaluated powdered milk samples (PM). The $C$. sakazakii isolates exhibited virulence factors, resistance genes to betalactam antibiotics, and a colistin ( $m r c$ 9.1) strain, which represent risk for infants consuming this product. Combined molecular methodologies based on WGS improve C. sakazakii identification and provide more reliable information for decision-making by health authorities to protect the infant population that consumes PM.

Author Contributions: Conceptualization, O.H. and J.P.-F.; methodology, O.H., J.P.-F., S.L., W.R., A.C.-C., J.M.-R and S.F.; software, S.L., J.P.-F., J.M.-R. and W.R.; validation, O.H., J.P.-F. and S.F.; formal analysis, O.H., J.P.-F. and S.F.; investigation, O.H., J.P.-F., A.C.-C., M.P.A.-L., S.L., W.R. and S.F.; resources, S.L., W.R., A.C.-C., M.P.A.-L., O.H., J.X.-C and J.P.-F.; data curation, S.L., O.H., J.M.-R. and J.P.-F.; writing-original draft preparation, O.H., J.P.-F., S.L., A.C.-C., M.P.A.-L., J.M.-R. and S.F.; supervision, S.L., W.R., O.H., J.X.-C., A.C.-C and J.P.-F.; project administration, O.H. and J.P.-F., S.L.; funding acquisition, O.H.; S.L., J.P.-F., W.R.; writing-review and editing, O.H., J.P.-F., S.F. All authors have read and agreed to the published version of the manuscript.

Funding: This research was funded the Research Directorate of the Universidad del Bío-Bío, Projects 191520 4/R and GI 195420/EF and, Research Support Foundation, Vaduz (991100531/39).

Acknowledgments: We thank the Institute of Medical Microbiology and Hygiene AGES-Austrian Agency for Health and Food Safety for their support.

Conflicts of Interest: The authors declare no conflict of interest.

\section{References}

1. Iversen, C.; Lehner, A.; Mullane, N.; Bidlas, E.; Cleenwerck, I.; Marugg, J.; Fanning, S.; Stephan, R.; Joosten, H. The taxonomy of Enterobacter sakazakii: Proposal of a new genus Cronobacter gen. nov.and descriptions of Cronobacter sakazakii comb. nov. Cronobacter sakazakii subsp. sakazakii, comb. nov., Cronobacter sakazakii subsp. malonaticus subsp. nov., Cronobacter turicensis sp. nov., Cronobacter muytjensii sp. nov., Cronobacter dublinensis sp. nov.and Cronobacter genomospecies 1. BMC Evol. Biol. 2007, 7, 64-74.

2. Iversen, C.; Mullane, N.; Mc Cardell, B.; Tall, B.; Lehner, A.; Fanning, S.; Stephan, R.; Joosten, H. Cronobacter gen. nov., a new genus to accommodate the biogroups of Enterobacter sakazakii, and proposal of Cronobacter sakazakii gen. nov.comb. nov., C. malonaticus sp. nov., C. turicensis sp. nov., C. muytjensii sp. nov., C. dublinensis sp. nov., Cronobacter genomospecies 1 , and of three subspecies, C. dublinensis sp. nov.subsp. dublinensis subsp. nov., C. dublinensis sp. nov.subsp. lausannensis subsp. nov., and C. dublinensis sp. nov.subsp. lactaridi subsp. nov. Int. J. Syst. Evol. Microbiol. 2008, 58, 1442-1447.

3. Joseph, S.; Cetinkaya, E.; Drahovska, H.; Levican, A.; Figueras, M.; Forsythe, S. Cronobacter condimenti sp. Nov., isolated from spiced meat, and Cronobacter universalis sp. Nov., a species designation for Cronobacter sp. Geneomoespecies 1, recovered from a leg infection, water and food ingredients. Int. J. Syst. Evol. Microbiol. 2012, 62, 1277-1283. [CrossRef]

4. Holý, O.; Petrželová, J.; Hanulík, V.; Chromá, M.; Matoušková, I.; Forsythe, S. Epidemiology of Cronobacter spp. isolates from patients admitted to the Olomouc University Hospital (Czech Republic). Epidemiol. Mikrobiol. Imunol. 2014, 63, 69-72. [PubMed]

5. Holý, O.; Forsythe, S. Cronobacter spp. as emerging causes of healthcare-associated infection. J. Hosp. Infect. 2014, 86, 169-177. [CrossRef]

6. Forsythe, S.J. Updates on the Cronobacter Genus. Annu. Rev. Food Sci. Technol. 2018, 25, 23-44. [CrossRef] [PubMed]

7. Bowen, A.; Braden, C. Invasive Enterobacter sakazakii disease in infants. Emerg. Infect. Dis. 2006, 12, 1185-1189. [CrossRef] [PubMed]

8. Stoll, B.J.; Hansen, N.; Fanaroff, A.; Lemons, J.A. Enterobacter sakazakii is a rare cause of neonatal septicemia or meningitis in VLBW infants. J. Pediatr. 2004, 144, 821-823. [PubMed]

9. Hunter, C.J.; Bean, J.F. Cronobacter: An emerging opportunistic pathogen associated with neonatal meningitis, sepsis and necrotizing enterocolitis. J. Perinatol. 2013, 33, 581-585. [CrossRef]

10. FAO; WHO. Enterobacter Sakazakii (Cronobacter spp) in Powdered Follow-Up Formulae; Microbiological Risk Assessment Series; WHO Press Publisher: Italy, Rome, 2008; Volume 15, pp. 1-105.

11. Baumgartner, A.; Grand, M.; Liniger, M.; Iversen, C. Detection and frequency of Cronobacter spp. (Enterobacter sakazakii) in different categories of ready-to-eat foods other than infant formula. Int. J. Food Microbiol. 2009, 136, 189-192. [CrossRef]

12. Kalyantanda, G.; Shumyak, L.; Archibald, L.K. Cronobacter species contamination of powdered infant formula and the implications for neonatal health. Front. Pediatr. 2015, 3, 56. [CrossRef] [PubMed]

13. Caubilla-Barron, J.; Forsythe, S. Dry stress and survival time of Enterobacter sakazakii and other Enterobacteriaceae in dehydrated powdered infant formula. J. Food Prot. 2007, 70, 2111-2117. [CrossRef] [PubMed] 
14. Chap, J.; Jackson, P.; Siqueira, R.; Gaspar, N.; Quintas, C.; Park, J.; Osaili, T.; Shaker, R.; Jaradat, Z.; Hartantyo, S.; et al. International survey of Cronobacter sakazakii and other Cronobacter spp. in follow up formulas and infant foods. Int. J. Food Microbiol. 2009, 136, 185-188. [CrossRef] [PubMed]

15. Siqueira, R.F.; da Silva, N.; Junqueira, V.; Kajsik, M.; Forsythe, S.; Pereira, J. Screening for Cronobacter species in powdered and reconstituted infant formulas and from equipment used in formula preparation in maternity hospitals. Ann. Nut. Met. 2013, 63, 62-68. [CrossRef] [PubMed]

16. Parra, J.; Oliveras, L.; Rodriguez, A.; Riffo, F.; Jackson, E.; Forsythe, S. Riesgo por Cronobacter sakazakii en leches en polvo para la nutrición de lactantes. Rev. Chil. Nut. 2015, 42, 83-89. [CrossRef]

17. Parra-Flores, J.; Maury-Sintjago, E.; Rodriguez-Fernández, A.; Acuña, S.; Cerda, F.; Aguirre, J.; Holý, O. Microbiological quality of powdered infant formula in Latin America. J. Food. Prot. 2020, 83, 534-541. [CrossRef]

18. Molloy, C.; Cagney, C.; O’Brien, S.; Iversen, C.; Fanning, S.; Duffy, G. Surveillance and characterization by Pulsed-Field Gel Electrophoresis of Cronobacter spp in farming and domestic environments, food production animals and retails foods. Int. J. Food Microbiol. 2009, 136, 198-238. [CrossRef]

19. Carvalho, G.; Calarga, A.; Teodoro, J.; Queiroz, M.; Astudillo-Trujillo, C.; Levy, C.; Brocchi, M.; Kabuki, D. Isolation, comparison of identification methods and antibiotic resistance of Cronobacter spp. in infant foods. Food Res. Int. 2020, 137, 109643. [CrossRef]

20. Parra-Flores, J.; Aguirre, J.; Juneja, V.; Jackson, E.; Cruz, A.; Silva, J.; Forsythe, S. Virulence and Antibiotic Resistance Profiles of Cronobacter sakazakii and Enterobacter spp. Involved in the Diarrheic Hemorrhagic Outbreak in Mexico. Front. Microbiol. 2018, 9, 2206. [CrossRef]

21. Fei, P.; Jiang, Y.; Yuan, X.; Yang, T.; Chen, J.; Wang, Z.; Kang, H.; Forsythe, S. Antibiotic and Desiccation Resistance of Cronobacter sakazakii and C. malonaticus Isolates from Powdered Infant Formula and Processing Environments. Front. Microbiol. 2017, 8, 316. [CrossRef]

22. Cruz, A.; Xicohtencatl, J.; Gonzalez, B.; Bobadilla, M.; Eslava, C.; Rosas, I. Virulence traits in Cronobacter species isolated from different sources. Can. J. Microbiol. 2011, 7, 735-744. [CrossRef] [PubMed]

23. Holý, O.; Cruz-Cordova, A.; Xicohtencatl-Cortés, J.; Hochel, I.; Parra-Flores, J.; Petrzelova, J.; Facevicova, K.; Forsythe, S.; Alsonosi, A. Occurrence of virulence factors in Cronobacter sakazakii and Cronobacter malonaticus originated from clinical samples. Microb. Pathog. 2019, 127, 250-256. [CrossRef] [PubMed]

24. Hamby, S.; Joseph, S.; Forsythe, S.; Chuzhanova, N. In Silico identification of pathogenic strains of Cronobacter from biochemical data reveals association of inositol fermentation with pathogenicity. BMC Microbiol. 2011, 11, 204-213. [CrossRef] [PubMed]

25. Townsend, S.; Hurrell, E.; Forsythe, S. Virulence studies of Enterobacter sakazakii isolates associated with a neonatal intensive care unit outbreak. BMC Microbiol. 2008, 8, 64. [CrossRef] [PubMed]

26. Franco, A.; Kothary, M.; Gopinath, G.; Jarvis, K.; Grim, C.; Hu, L.; Datta, A.; McCardell, B.A.; Tall, B.D. Cpa, the outer membrane protease of Cronobacter sakazakii, activates plasminogen and mediates resistance to serum bactericidal activity. Infect. Immun. 2011, 79, 1578-1587. [CrossRef] [PubMed]

27. Cruz-Córdova, A.; Rocha-Ramírez, L.; Ochoa, S.; Gónzalez-Pedrajo, B.; Espinosa, N.; Eslava, C.; Hernández-Chiñas, U.; MendozaHernández, G.; Rodríguez-Leviz, A.; Valencia-Mayoral, P.; et al. Flagella from five Cronobacter species induce pro-inflammatory cytokines in macrophage derivatives from human monocytes. PLOS ONE 2012, 7, e52091. [CrossRef]

28. Kim, K.; Kim, K.; Choi, J.; Lim-Jeong, A.; Lee, J.; Hwang, S.; Ryu, S. Outer Membrane Proteins A (OmpA) and X (OmpX) Are Essential for Basolateral Invasion of Cronobacter sakazakii. Appl. Environ. Microbiol. 2010, 76, 5188-5198. [CrossRef]

29. Ogrodzki, P.; Forsythe, S. Capsular profiling of the Cronobacter genus and the association of specific Cronobacter sakazakii and C. malonaticus capsule types with neonatal meningitis and necrotizing enterocolitis. BMC Genom. 2015, 16, 758. [CrossRef]

30. Masood, N.; Moore, K.; Farbos, A.; Hariri, S.; Block, C.; Paszkiewicz, K.; Dickins, B.; McNally, A.; Forsythe, S. Draft Genome Sequence of a Meningitic Isolate of Cronobacter sakazakii Clonal Complex 4, Strain 8399. Genome Announc. 2013, 1, e00833-13. [CrossRef]

31. Ogrodzki, P.; Forsythe, S.J. DNA-Sequence Based Typing of the Cronobacter Genus Using MLST, CRISPR-cas Array and Capsular Profiling. Front. Microbiol. 2017, 8, 1875. [CrossRef]

32. Jolany vangah, S.; Katalani, C.; Boone, H.; Abbas Hajizade, A.; Ahmadian, G. CRISPR-Based Diagnosis of Infectious and Noninfectious Diseases. Biol. Proced. Online 2020, 22, 22. [CrossRef] [PubMed]

33. Baldwin, A.; Loughlin, M.; Caubilla-Barron, J.; Kucerova, E.; Manning, G.; Dowson, C.; Forsythe, S. Multilocus sequence typing of Cronobacter sakazakii and Cronobacter malonaticus reveals stable clonal structures with clinical significance, which do not correlate with biotypes. BMC Microbiol. 2009, 9, 223. [CrossRef] [PubMed]

34. Forsythe, S.J.; Dickins, B.; Jolley, K.A. Cronobacter, the emergent bacterial pathogen Enterobacter sakazakii comes of age; MLST and whole genome sequence analysis. BMC Genom. 2014, 15, 1121. [CrossRef] [PubMed]

35. Grad, Y.; Lipsitch, M. Epidemiologic data and pathogen genome sequences: A powerful synergy for public health. Genome Biol. 2014, 15, 538. [CrossRef]

36. Iversen, C.; Forsythe, S.J. Isolation of Enterobacter sakazakii and other Enterobacteriaceae from powdered infant formula milk and related products. Food Microbiol. 2004, 21,771-776. [CrossRef]

37. Lepuschitz, S.; Sorschag, S.; Springer, B.; Allerberger, F.; Ruppitsch, W. Draft genome sequence of carbapenemase-producing Serratia marcescens isolated from a patient with chronic obstructive pulmonary disease. Genome Announc. 2017, 5, e01288-17. [CrossRef] 
38. Lepuschitz, S.; Ruppitsch, W.; Pekard-Amenitsch, S.; Forsythe, S.J.; Cormican, M.; Mach, R.L.; Piérard, D.; Allerberger, F.; the EUCRONI Study Group. Multicenter Study of Cronobacter sakazakii Infections in Humans, Europe, 2017. Emerg. Infect. Dis. 2019, 25, 515-522. [CrossRef]

39. Bankevich, A.; Nurk, S.; Antipov, D.; Gurevich, A.A.; Dvorkin, M.; Kulikov, A.S.; Lesin, V.M.; Nikolenko, S.; Pham, S.; Prjibelski, A.; et al. SPAdes: A new genome assembly algorithm and its applications to single-cell sequencing. J. Comput. Biol. 2012, 19, 455-477. [CrossRef]

40. Ruppitsch, W.; Pietzka, A.; Prior, K.; Bletz, S.; Fernandez, H.L.; Allerberger, F.; Harmsen, D.; Mellmann, A. Defining and evaluating a core genome MLST scheme for whole genome sequence-based typing of Listeria monocytogenes. J. Clin. Microbiol. 2015, 53, 2869-2876. [CrossRef]

41. Jia, B.; Raphenya, A.R.; Alcock, B.; Waglechner, N.; Guo, P.; Tsang, K.; Lago, B.; Dave, B.; Pereira, S.; Sharma, A.; et al. CARD 2017: Expansion and model-centric curation of the comprehensive antibiotic resistance database. Nucleic Acids Res. 2017, 45, D566-D573. [CrossRef]

42. Carattoli, A.; Zankari, E.; García-Fernández, A.; Voldby-Larsen, M.; Lund, O.; Villa, L.; Møller-Aarestrup, F.; Hasman, H. In silico detection and typing of plasmids using PlasmidFinder and plasmid multilocus sequence typing. Antimicrob. Agents Chemother. 2014, 58, 3895-3903. [CrossRef] [PubMed]

43. Couvin, D.; Bernheim, A.; Toffano-Nioche, C.; Touchon, M.; Michalik, J.; Néron, B.; Rocha, E.; Vergnaud, G.; Gautheret, D.; Pourcel, C. CRISPRCasFinder, an update of CRISRFinder, includes a portable version, enhanced performance and integrates search for Cas proteins. Nucleic Acids Res. 2018, 46, 246-251. [CrossRef]

44. Ge, R.; Mai, G.; Wang, P.; Zhou, M.; Luo, Y.; Cai, Y.; Zhou, F. CRISPRdigger: Detecting CRISPRs with better direct repeat annotations. Sci. Rep. 2016, 6, 32942. [CrossRef] [PubMed]

45. Joseph, S.; Forsythe, S. Insights into the emergent bacterial pathogen Cronobacter spp., generated by multilocus sequence typing and analysis. Front. Food Microbiol. 2012, 3, 397. [CrossRef] [PubMed]

46. Dugan, K. Advances in Understanding Bacterial Pathogenesis Gained from Whole-Genome Sequencing and Phylogenetics. Cell Host Microbe 2016, 19, 599-610.

47. Hunter, C.J.; Singamsetty, V.K.; Chokshi, N.K.; Boyle, P.; Camerini, V.; Grishin, A.V.; Upperman, J.S.; Ford, H.R.; Prasadarao, N.V. Enterobacter sakazakii enhances epithelial cell injury by inducing apoptosis in a rat model of necrotizing enterocolitis. J Infect. Dis. 2008, 198, 586-593. [CrossRef]

48. Mange, J.P.; Stephan, R.; Borel, L.; Wild, P.; Kim, K.S.; Pospischil, A.; Lenher, A. Adhesive properties of Enterobacter sakazakii to human epithelial and brain microvascular endothelial cells. BMC Microbiol. 2006, 6, 58-68. [CrossRef]

49. Townsend, S.; Hurrell, E.; Gonzalez-Gomez, I.; Lowe, J.; Frye, J.; Forsythe, S.; Badger, J. Enterobacter sakazakii invades brain capillary endothelial cells, persists in human macrophages influencing cytokine secretion and induces severe brain pathology in the neonatal rat. Microbiology 2007, 153, 3538-3547. [CrossRef]

50. Ye, Y.; Li, H.; Ling, N.; Han, Y.; Wu, Q.; Xu, X.; Jiao, R.; Gao, J. Identification of potential virulence factors of Cronobacter sakazakii isolates by comparative proteomic analysis. Int. J. Food Microbiol. 2016, 217, 182-188. [CrossRef]

51. Quintero-Villegas, M.; Wittke, A.; Hutkins, R. Adherence Inhibition of Cronobacter sakazakii to Intestinal Epithelial Cells by Lactoferrin. Curr. Microbiol. 2014, 69, 574-579. [CrossRef]

52. Alsonosi, A.; Holý, O.; Forsythe, S. Characterization of the pathogenicity of clinical Cronobacter malonaticus strains based on the tissue culture investigations. Antonie Leeuwenhoek. 2019, 112, 435-450. [CrossRef] [PubMed]

53. Wu, H.; Andrew, H.-J.; Wang, A.; Jennings, M. Discovery of virulence factors of pathogenic bacteria. Curr. Opin. Chem. Biol. 2008, 12, 1-9. [CrossRef] [PubMed]

54. Papadopoulos, D.; Schneider, D.; Meier-Eiss, J.; Arber, W.; Lenski, R.; Blot, M. Genomic evolution during a 10,000-generation experiment with bacteria. Proc. Natl. Acad. Sci. USA 1999, 96, 3807-3812. [CrossRef] [PubMed]

55. Nair, M.K.M.; Venkitanarayanan, K. Role of bacterial OmpA and host citoskeleton in the invasion of human intestinal epithelial cells by Enterobacter sakazakii. Pediatr. Res. 2007, 62, 664-669. [CrossRef] [PubMed]

56. Jang, H.; Chase, H.R.; Gangiredla, J.; Grim, C.J.; Patel, I.R.; Kothary, M.H.; Jackson, S.; Mammel, M.K.; Carter, L.; Negrete, F.; et al. Analysis of the molecular diversity among Cronobacter species isolated from filth flies using targeted PCR, pan genomic DNA microarray, and whole genome sequencing analyses. Front. Microbiol. 2020, 11, 561204. [CrossRef]

57. Baida, G.E.; Kuzmin, N.P. Mechanism of action of hemolysin III from Bacillus cereus. Biochim. Biophys. Acta 1996, 1284, $22-124$. [CrossRef]

58. Chen, Y.C.; Chang, M.C.; Chuang, Y.C.; Jeang, C.L. Characterization and virulence of hemolysin III from Vibrio vulnificus. Curr. Microbiol. 2004, 49, 175-179. [CrossRef]

59. Himelright, I.; Harris, E.; Lorch, V.; Anderson, M. Enterobacter sakazakii infections associated with the use of powdered infant formula-Tennessee, 2001. J. Am. Med. Assoc. 2002, 287, 2204-2205.

60. Abreu, A.; Bueris, V.; Porangaba, T.; Sircili, M.; Navarro-Garcia, F.; Elias, W. Autotransporter Protein-Encoding Genes of Diarrheagenic Escherichia coli Are Found in both Typical and Atypical Enteropathogenic E. coli Strains. Appl. Environ. Microbiol. 2013, 79, 411-414. [CrossRef]

61. Proudy, I.; Bouglé, D.; Coton, E.; Coton, M.; Leclercq, R.; Vergnaud, M. Genotypic characterization of Enterobacter sakazakii isolates by PFGE, BOX-PCR and sequencing of the fliC gene. J. Appl. Microbiol. 2008, 104, 26-34. [CrossRef] 
62. Hoeflinger, J.L.; Miller, M.J. Cronobacter sakazakii ATCC 29544 Autoaggregation requires FliC flagellation, not motility. Front. Microbiol. 2017, 8, 301. [CrossRef] [PubMed]

63. Aldubyan, M.; Almami, I.; Benslimane, F.; Alsonosi, A.; Forsythe, S. Comparative Outer Membrane Protein Analysis of High and Low-Invasive Strains of Cronobacter malonaticus. Front. Microbiol. 2017, 8, 2268. [CrossRef] [PubMed]

64. Dingle, T.; Mulvey, G.; Armstrong, G. Mutagenic analysis of the Clostridium difficile flagellar proteins, FliC and FliD, and their contribution to virulence in hamsters. Infect. Immun. 2011, 79, 4061-4067. [CrossRef]

65. Ye, Y.; Zhang, X.; Zhang, M.; Ling, N.; Zeng, H.; Gao, J.; Jiao, R.; Wu, Q.; Zhang, J. Potential factors involved in virulence of Cronobacter sakazakii isolates by comparative transcriptome analysis. J. Dairy Sci. 2017, 100, 8826-8837. [CrossRef]

66. Kim, K.; Jang, S.; Kim, S.; Park, J.; Heu, S.; Ryu, S. Prevalence and genetic diversity of Enterobacter sakazakii in ingredients of infant foods. Int. J. Food Microbiol. 2008, 122, 196-203. [CrossRef] [PubMed]

67. Chon, J.; Song, K.; Kim, S.; Hyeon, J.; Seo, K. Isolation and characterization of Cronobacter from desiccated foods in Korea. J. Food Sci. 2012, 77, 354-358. [CrossRef] [PubMed]

68. Parra-Flores, J.; Arvizu, S.; Silva, J.; Fernández, E. Two cases of hemorrhagic diarrhea caused by Cronobacter sakazakii in hospitalized nursing infants associated with the consumption of powdered infant formula. J. Food Prot. 2011, 74, 2177-2181. [CrossRef]

69. Aly, M.A.; Domig, K.J.; Kneifel, W.; Reimhult, E. Whole Genome Sequencing-Based Comparison of Food Isolates of Cronobacter sakazakii. Front. Microbiol. 2019, 10, 1464. [CrossRef]

70. Touze, T.; Eswaran, J.; Bokma, E.; Koronakis, E.; Hughes, C.; Koronakis, V. Interactions underlying assembly of the Escherichia coli AcrAB-TolC multidrug efflux system. Mol. Microbiol. 2004, 53, 697-706. [CrossRef]

71. Kucerova, E.; Clifton, S.W.; Xia, X.Q.; Long, F.; Porwollik, S.; Fulton, L.; Feng, D.; Wollam, A.; Shah, N.; Bhonogiri, V.; et al. Genome sequence of Cronobacter sakazakii BAA-894 and comparative genomic hybridization analysis with other Cronobacter species. PLoS ONE 2010, 5, e9556. [CrossRef]

72. El-Sharoud, W.; O’Brien, S.; Negredo, C.; Iversen, C.; Fanning, S.; Healy, B. Characterization of Cronobacter recovered from dried milk and related products. BMC Microbiol. 2009, 9, 9. [CrossRef] [PubMed]

73. Carroll, L.; Gaballa, A.; Guldimann, C.; Sullivan, G.; Henderson, L.; Wiedmann, M. Identification of Novel Mobilized Colistin Resistance Gene mcr-9 in a Multidrug-Resistant, Colistin-Susceptible Salmonella enterica Serotype Typhimurium Isolate. mBio 2019, 10, e00853-19. [CrossRef] [PubMed]

74. Kieffer, N.; Royer, G.; Decousser, J.-W.; Bourrel, A.-S.; Palmieri, M.; Ortiz De La Rosa, J.-M.; Jacquier, H.; Denamur, E.; Nordmann, P.; Poirel, L. mcr-9, an Inducible Gene Encoding an Acquired Phosphoethanolamine Transferase in Escherichia coli, and Its Origin. Antimicrob. Agents Chemother. 2019, 63, e00965-19. [CrossRef] [PubMed]

75. Yuan, Y.; Li, Y.; Wang, G.; Li, C.; Xiang, L.; She, J.; Yang, Y.; Zhong, F.; Zhang, L. Coproduction of MCR-9 and NDM-1 By Colistin-Resistant Enterobacter hormaechei Isolated from Bloodstream Infection. Infect. Drug Resist. 2019, 12, 2979-2985. [CrossRef] [PubMed]

76. Cheng, Y.; Chen, Y.; Liu, Y.; Guo, Y.; Zhou, Y.; Xiao, T.; Zhang, S.; Xu, H.; Chen, Y.; Shan, T.; et al. Identification of novel tetracycline resistance gene tet $(\mathrm{X} 14)$ and its co-occurrence with tet $(\mathrm{X} 2)$ in a tigecycline-resistant and colistin-resistant Empedobacter stercoris. Emerg. Microbes Infect. 2020, 9, 1843-1852. [CrossRef] [PubMed]

77. Müller, A.; Hächler, H.; Stephan, R.; Lehner, A. Presence of AmpC beta-lactamases, CSA-1, CSA-2, CMA-1, and CMA-2 conferring an unusual resistance phenotype in Cronobacter sakazakii and Cronobacter malonaticus. Microb. Drug Resist. 2014, 20, 275-280. [CrossRef]

78. Zhou, K.; Zhou, Y.; Zhang, C.; Song, J.; Cao, X.; Yu, X.; Shen, P.; Xiao, Y. Dissemination of a 'rare' extended-spectrum $\beta$ lactamase gene blaSFO-1 mediated by epidemic clones of carbapenemase-producing Enterobacter hormaechei in China. Int. J. Antimicrob. Agents 2020, 56, 106079. [CrossRef]

79. Eshwar, A.K.; Tall, B.D.; Gangiredla, J.; Gopinath, G.R.; Patel, I.R.; Neuhauss, S.; Stephan, R.; Lehner, A. Linking Genomo- and Pathotype: Exploiting the Zebrafish Embryo Model to Investigate the Divergent Virulence Potential among Cronobacter spp. PLoS ONE 2016, 11, e0158428. [CrossRef]

80. Makarova, K.S.; Koonin, E.V. Annotation and Classification of CRISPR-Cas Systems. Methods Mol. Biol. 2015, 1311, 47-75.

81. Ogrodzki, P.; Forsythe, J. CRISPR-cas loci profiling of Cronobacter sakazakii pathovars. Future Microbiol. 2016, 11, 1507-1519. [CrossRef]

82. Zeng, H.; Li, C.; He, W.; Zhang, J.; Chen, M.; Lei, T.; Wu, H.; Ling, N.; Cai, S.; Wang, J.; et al. Cronobacter sakazakii, Cronobacter malonaticus, and Cronobacter dublinensis Genotyping Based on CRISPR Locus Diversity. Front. Microbiol. 2019, 10, 1989. [CrossRef] [PubMed]

83. Zeng, H.; Zhang, J.; Li, C.; Xie, T.; Ling, N.; Wu, Q.; Ye, Y. The driving force of prophages and CRISPR-Cas system in the evolution of Cronobacter sakazakii. Sci. Rep. 2017, 7, 40206. [CrossRef] [PubMed]

84. Zeng, H.; Zhang, J.; Wu, Q.; He, W.; Wu, H.; Ye, Y.; Li, C.; Ling, N.; Chen, M.; Wang, J.; et al. Reconstituting the History of Cronobacter Evolution Driven by Differentiated CRISPR Activity. Appl. Environ. Microbiol. 2018, 84, e00267-18. [CrossRef] [PubMed] 